\title{
Effect of Habbul Ghar and Maul Asal in Primary Dysmenorrhea- A Randomized standard controlled clinical study.
}

\author{
Dr Hina Mukhtar ${ }^{1}$, Prof. Wajeeha Begum ${ }^{2}$, Dr Fozia Mukhtar ${ }^{3}$ \\ ${ }^{1}$ Assistant Prof, Deptt of Ilmul Qabalat Wa Amraz-e-Niswan, Sanskriti University Chatta Mathura. \\ ${ }^{2}$ Prof, HOD, Deptt of Ilmul Qabalat wa Amraze Niswan, NIUM, RGUHS, Bangalore, India. \\ ${ }^{3}$ Assistant prof, Dept of Ilmul Atfal Glocal university Saharanpur. \\ DOI: 10.29322/IJSRP.10.07.2020.p10378 \\ http://dx.doi.org/10.29322/IJSRP.10.07.2020.p10378
}

\begin{abstract}
Abstract: It is characterized by severe uterine pain during menstruation. It is a very common complaint, experienced by $45-95 \%$ of reproductive age group women. Prostaglandins are known to increase myometrial contraction and constrict small endometrial blood vessels to produce ischemia and pain, the aim of the study is to evaluate the Effect of Habbul Ghar and Maul Asal in Primary Dysmenorrhea

Method: This is single blind randomized standard controlled study. Inclusion Criteria-Patients with regular menstrual cycle and painful menstruation and exclusion criteria are intra uterine contraceptive devices, organic pelvic pathology, systemic illness, allergic /sensitive to NSAIDs. 4.5gms Habbul ghar is powdered and mixed with qand to form pills, 2 pills TID along with Maul Asal $20 \mathrm{ml}$ from first day of menses up to 5 days. Primary and secondary outcome was assessed. Visual Analogue scale (VAS) Score and Verbal Multidimensional scoring system (VMSS).

Result: Marked improvement in dysmenorrhea was observed in both the groups. VAS mean score before and after treatment is $7.67 \pm 1.4$ vs $5.70 \pm 1.26$ in test group and in control group it is $7.43 \pm 1.28$ vs $5.97 \pm 1.16$ with a p value of (p<0.001**). In VMSS mean score before and after treatment is $2.47 \pm 0.68$ vs $1.73 \pm 0.45$ in the test group and in control group it is $2.40 \pm 0.50$ vs $2.00 \pm 0.26$ with a $\mathrm{p}$ value $\left(\mathrm{p}<0.001^{* *}\right)$. Significant improvement is found in subjective and objective parameters of both the groups.

Interpretation and conclusion: This data suggests that both drugs were safe, effective in improving and relieving symptoms of dysmenorrhea, and test drug is equally effective as control drug. Further, research is certified in larger sample size for longer duration is recommended.
\end{abstract}

Index Terms- Habbul ghar: dysmenorrhea: Maul Asal: VAS: VMSS.

\section{Introduction:}

${ }^{1}$ It is a medical condition characterized by severe uterine pain during menstruation. ${ }^{2}$ According to ACOG pain associated with menstruation is called as dysmenorrhea. The major cause of absenteeism from work amongst young women thus decreasing efficiency and quality of life among affected women. ${ }^{1}$ The incidence of primary dysmenorrhea of sufficient magnitude with incapacitation is about $15-20 \% .^{3}$ It is a very common complaint, experienced by $45-95 \%$ of women of reproductive age group. The term primary dysmenorrhea is described as cyclic menstrual pain without any identifiable associated pathology, whereas secondary dysmenorrhea frequently complicate endometriosis, of the uterus leading to uterine hypoxia and ischemia, which are believed to cause pain and cramps in primary dysmenorrhea. ${ }^{6}$

In classical unani literature, usr-i-tamth has been described as dard al-rahim or auja'-al rahim. The pain usually occurs in the uterus and spreads to the surrounding areas. It has been mentioned that any obstruction to the flow of menstrual blood alters the temperament $\left(s \bar{u}^{\prime}-i-m i z \bar{a} j\right)$ resulting in difficult or leiomyomas, PID, adenomyosis, endometrial polyp and menstrual outlet obstruction. ${ }^{4}$ Primary dysmenorrhea's characteristic symptom is cramps, colicky spasms of pain in the suprapubic area, occurring within 8-72 hours of menstruation and peaking within the first few days as menstrual flow increases. In addition to painful cramps, many women with primary dysmenorrhea experience other menstrual-related symptoms, including back and thigh pain, headaches, diarrhoea, nausea and vomiting ${ }^{5}$. Excess production and release of prostaglandins during menstruation by the endometrium cause hyper contractility

painful menstruation. Habbul Ghar possesses musakkine aujaa, muhallile warm, mudire haiz properties. ${ }^{5,6,7}$ It helps in easy flow of menstruation and relieve the pain. The aim is to validate scientifically the effect of Habbul Ghar in dard al-rahim.

Materials and Methods:

Study design: Single blind randomized standard controlled study. was carried out from January 2018 to December 2018 in Dept. of OBG National Institute of 
ISSN 2250-3153

Unani Medicine hospital, Bengaluru. Ethical clearance was obtained from institutional ethical committee vide no. (IEC-No.-NIUM/ICE/2016-2017/013/ANQ/05) approved this study, and CTRI/2018/03/012646.

Sample size calculation: Sample size was calculated by using formula

$n=2 \times\left\{\frac{(\mathrm{Z} \alpha / 2+Z 1-\beta)(\sigma)}{r d}\right\}^{2}$

$\mathrm{n}=$ sample size required, $\mathrm{d}=$ Expected clinical significant difference in vomiting (mean difference) $=$ 9

$\sigma=$ Pooled standard deviation $=18.3$

$\mathrm{Z}_{\alpha / 2}=1.96$ for $\mathrm{P}<.05, \mathrm{Z}_{1-\beta}=0.84 \mathrm{r}=1$ (ratio= $\left.1: 1\right)$, The sample size calculated was 62.72 .

Selection criteria: Patients with age group of 18-35 years. ${ }^{8}$

Patients with regular menstrual cycle and painful menstruation.

Exclusion criteria: Intra uterine contraceptive devices.

Organic pelvic pathology.

Systemic illness.

Allergic /sensitive to NSAIDs.

\section{Participants:}

60 patients were allocated by computer generated randomization chart into 2 blocks. 30 patients in the test (group A) and 30 patients in the control (group B) were included.

\section{Investigations:}

Following investigations were carried out in each case to exclude the patients with pathological conditions

patients (18 in the test group and 12 in control group) after treatment in objective parameters i.e. VAS and VMSS in test and control group respectively. VAS in before treatment it was $7.43 \pm 1.28$ and after treatment it was $5.97 \pm 1.16$ which was statistically strongly.

\section{Objective parameters:}

Visual Analogue scale (VAS) Score.

Verbal Multidimensional scoring system (VMSS).

significant $(p<0.001)$ in both the groups. In test group mean score of VMSS before treatment was $2.47 \pm 0.68$ and after treatment it was $1.73 \pm 0.45$ where as in the control group mean score of VMSS before treatment it was $2.40 \pm 0.50$ and after treatment it was $2.00 \pm 0.26$ which was statistically strongly significant $(\mathrm{p}<0.001)$ in both groups

\section{Results:}

Demographic distribution in test and control groups of dysmenorrhea patients

\begin{tabular}{|c|c|c|c|c|}
\hline Features & $\begin{array}{c}\text { Test group } \\
n=30\end{array}$ & $\begin{array}{c}\begin{array}{c}\text { Control group } \\
n=30\end{array} \\
\end{array}$ & Total & $\begin{array}{l}\text { P value \& } \\
\text { Test used }\end{array}$ \\
\hline \multicolumn{5}{|l|}{ Age in years } \\
\hline$<20$ & $9(30 \%)$ & $8(26.7 \%)$ & $17(28.3 \%)$ & \multirow{5}{*}{$\begin{array}{c}\mathrm{P}=0.294 \\
\text { Student } \\
\mathrm{t} \text { test }\end{array}$} \\
\hline $20-30$ & $13(43.3 \%)$ & $12(40 \%)$ & $25(41.7 \%)$ & \\
\hline $31-40$ & $8(26.7 \%)$ & $10(33.3 \%)$ & $18(30 \%)$ & \\
\hline Total & $30(100 \%)$ & $30(100 \%)$ & $60(100 \%)$ & \\
\hline Mean \pm SD & $24.33 \pm 6.61$ & $26.13 \pm 6.56$ & $25.23 \pm 6.59$ & \\
\hline
\end{tabular}

This publication is licensed under Creative Commons Attribution CC BY.

For exclusion: Haemoglobin, RBS, USG - Pelvis.

Safety profile: LFT (SGOT, SGPT, Alkaline Phosphatase) and RFT (Blood Urea, Serum creatinine).

Intervention:

Control group: Mefenamic acid $500 \mathrm{mg}$ BD from first day of menses to 5 days.

Test group: Pills form as per standard preparation.

Dosage and duration: $4.5 \mathrm{gms}$ Habbul-ghar is powdered and mixed with qand to form pills, 2 pills TID along with Maul Asal $20 \mathrm{ml}$ from first day of ays?

parameters Painful menstruation Study procedure: Patients complaining of dysmenorrhea symptoms like uterine cramping, nausea, vomiting, backache, diarrhoea, giddiness, syncope and fainting.

Patients were clinically examined and required haematological and biochemical investigations were done. The patients fulfilling the inclusion criteria were given informed consent form and written consent taken and included in the study.

Treatment outcome:

Thed on primary outcome out of 60 patients changed in all 30 patients (18 in test group and 12 in te relief, partial relief and no relief in subjective parameters before and after treatment as follows:
Based on secondary outcome out of 60 patients

test group mean score was $7.67 \pm 1.4$ before treatment

and after treatment $5.70 \pm 1.26$ where as in control group mean score

mentioned under exclusion criteria and to assess the found in all 30 pa changed was found in 30 


\begin{tabular}{|c|c|c|c|c|}
\hline \multicolumn{5}{|c|}{ Socio economic status } \\
\hline Lower Middle & $11(36.7 \%)$ & $7(23.3 \%)$ & $18(30 \%)$ & \multirow{5}{*}{$\begin{array}{l}\mathrm{P}=0.046^{*}, \\
\text { Fisher Exact } \\
\text { Test }\end{array}$} \\
\hline Upper & $4(13.3 \%)$ & $3(10 \%)$ & $7(11.7 \%)$ & \\
\hline Upper Lower & $4(13.3 \%)$ & $14(46.7 \%)$ & $18(30 \%)$ & \\
\hline Upper Middle & $11(36.7 \%)$ & $6(20 \%)$ & $17(28.3 \%)$ & \\
\hline Total & $30(100 \%)$ & $30(100 \%)$ & $60(100 \%)$ & \\
\hline
\end{tabular}

\begin{tabular}{|l|l|l|l|}
\hline Education & $30(100 \%)$ & $30(100 \%)$ & $60(100 \%)$ \\
\hline
\end{tabular}

\begin{tabular}{|c|c|c|c|c|}
\hline Illiterate & $2(6.7 \%)$ & $2(6.7 \%)$ & $4(6.7 \%)$ & \multirow{7}{*}{$\begin{array}{c}\mathrm{P}=0.271 \\
\text { Fisher Exact } \\
\text { Test }\end{array}$} \\
\hline Primary & $2(6.7 \%)$ & $2(6.7 \%)$ & $4(6.7 \%)$ & \\
\hline Secondary & $7(23.3 \%)$ & $12(40 \%)$ & $19(31.7 \%)$ & \\
\hline High School & $4(13.3 \%)$ & $7(23.3 \%)$ & $13(21.7 \%)$ & \\
\hline Graduation & $12(40 \%)$ & $4(13.3 \%)$ & $16(26.7 \%)$ & \\
\hline Post-Graduation & $3(10 \%)$ & $3(10 \%)$ & $6(10 \%)$ & \\
\hline Total & $30(100 \%)$ & $30(100 \%)$ & $60(100 \%)$ & \\
\hline \multicolumn{4}{|l|}{ Habitat } & \\
\hline Rural & $1(3.3 \%)$ & $1(3.3 \%)$ & $2(3.3 \%)$ & \multirow{3}{*}{$\begin{array}{c}\mathrm{P}=1.000, \\
\text { Fisher Exact } \\
\text { Test }\end{array}$} \\
\hline Urban & $29(96.7 \%)$ & $29(96.7 \%)$ & $58(96.7 \%)$ & \\
\hline Total & $30(100 \%)$ & $30(100 \%)$ & $60(100 \%)$ & \\
\hline \multicolumn{5}{|l|}{ Diet } \\
\hline Mixed & $21(70 \%)$ & $17(56.7 \%)$ & $38(63.3 \%)$ & \multirow{3}{*}{$\begin{array}{c}\mathrm{P}=0.284 \\
\text { Chi }=\text { Square } \\
\text { Test }\end{array}$} \\
\hline Veg & $9(30 \%)$ & $13(43.3 \%)$ & $22(36.7 \%)$ & \\
\hline Total & $30(100 \%)$ & $30(100 \%)$ & $60(100 \%)$ & \\
\hline \multicolumn{5}{|l|}{ Religion } \\
\hline Muslim & $19(63.3 \%)$ & $17(56.7 \%)$ & $36(60 \%)$ & \multirow{3}{*}{$\begin{array}{c}\mathrm{P}=0.598, \text { not } \\
\text { significant, } \\
\text { chi-square } \\
\text { test }\end{array}$} \\
\hline Non-Muslim & $11(36.7 \%)$ & $13(43.3 \%)$ & $24(40 \%)$ & \\
\hline Total & $30(100 \%)$ & $30(100 \%)$ & $60(100 \%)$ & \\
\hline
\end{tabular}

Table 3: Age at menarche in test and control groups in Dysmenorrhea patients.

\begin{tabular}{|l|c|c|c|}
\hline \multicolumn{1}{|c|}{ Age at menarche } & Test group & Control group & Total \\
\hline 11 & $4(13.3 \%)$ & $5(16.7 \%)$ & $9(15 \%)$ \\
\hline 12 & $17(56.7 \%)$ & $9(30 \%)$ & $26(43.3 \%)$ \\
\hline 13 & $7(23.3 \%)$ & $15(50 \%)$ & $22(36.7 \%)$ \\
\hline 14 & $0(0 \%)$ & $1(3.3 \%)$ & $1(1.7 \%)$ \\
\hline 15 & $2(6.7 \%)$ & $0(0 \%)$ & $2(3.3 \%)$ \\
\hline Total & $30(100 \%)$ & $30(100 \%)$ & $60(100 \%)$ \\
\hline Mean \pm SD & $12.30 \pm 0.95$ & $12.40 \pm 0.81$ & $12.35 \pm 0.88$ \\
\hline
\end{tabular}

$\mathrm{P}=0.664$, Not Significant, Student $\mathrm{t}$ test

Mizaj distribution in test and control groups of dysmenorrhea patients.

\begin{tabular}{|l|c|c|c|c|}
\hline Mizaj & $\begin{array}{c}\text { Test group } \\
\mathbf{n = 3 0}\end{array}$ & $\begin{array}{c}\text { Control group } \\
\mathbf{n}=\mathbf{3 0}\end{array}$ & Total & $\begin{array}{c}\text { P value \& } \\
\text { test used }\end{array}$ \\
\hline Damwi & $10(33.3 \%)$ & $11(36.7 \%)$ & $21(35 \%)$ & $\mathrm{P}=0.284$ \\
\hline
\end{tabular}




\begin{tabular}{|c|c|c|c|c|}
\hline Sawdāwi & $7(23.3 \%)$ & $10(33.3 \%)$ & $17(28.3 \%)$ & $\begin{array}{c}\text { Fisher Exact } \\
\text { Test }\end{array}$ \\
\hline Balgami & $7(23.3 \%)$ & $8(26.7 \%)$ & $15(25 \%)$ & \\
\hline Safrāwi & $6(20 \%)$ & $1(3.3 \%)$ & $7(11.7 \%)$ & \\
\hline Total & $30(100 \%)$ & $30(100 \%)$ & $60(100 \%)$ & \\
\hline
\end{tabular}

Visual analogue scale- a comparative assessment in test and control groups of dysmenorrhea patients.

\begin{tabular}{|l|c|c|c|c|}
\hline $\begin{array}{c}\text { Visual } \\
\text { analogue scale }\end{array}$ & Test group & Control group & Total & P value \\
\hline Before treatment & $7.67 \pm 1.4$ & $7.43 \pm 1.28$ & $7.55 \pm 1.33$ & 0.503 \\
\hline After treatment & $5.70 \pm 1.26$ & $5.97 \pm 1.16$ & $5.83 \pm 1.21$ & 0.398 \\
\hline Difference & 1.967 & 1.467 & 1.717 & - \\
\hline t value & 13.320 & 10.351 & 16.113 & - \\
\hline p value & $<0.001 * *$ & $<0.001 * *$ & $<0.001 * *$ & \\
\hline
\end{tabular}

Verbal multidimensional scoring system- a comparative assessment in test and control groups of dysmenorrhea patients

\begin{tabular}{|l|c|c|c|c|}
\hline $\begin{array}{c}\text { Verbal } \\
\text { scoring system }\end{array}$ & Test group & Control group & Total & P value \\
\hline Before treatment & $2.47 \pm 0.68$ & $2.40 \pm 0.50$ & $2.43 \pm 0.59$ & 0.667 \\
\hline After treatment & $1.73 \pm 0.45$ & $2.00 \pm 0.26$ & $1.87 \pm 0.39$ & $0.007 * *$ \\
\hline Difference & 0.732 & 0.400 & 0.567 & - \\
\hline $\mathrm{t}$ value & 6.886 & 4.397 & 7.790 & - \\
\hline $\mathrm{p}$ value & $<0.001 * *$ & $<0.001 * *$ & $<0.001 * *$ & - \\
\hline
\end{tabular}

Safety parameters- a comparative assessment at different study time points in two groups studied

\begin{tabular}{|c|c|c|c|c|}
\hline Variables & $\begin{array}{c}\text { Test group } \\
n=30\end{array}$ & $\begin{array}{c}\text { Control group } \\
n=30\end{array}$ & Total & $P$ value \\
\hline \multicolumn{5}{|l|}{ SGOT(IU/L) } \\
\hline - $\quad$ Before treatment & $21.85 \pm 7.32$ & $23.50 \pm 7.53$ & $22.68 \pm 7.41$ & 0.393 \\
\hline - $\quad$ After treatment & $19.87 \pm 6.54$ & $21.50 \pm 8.85$ & $20.68 \pm 7.76$ & 0.420 \\
\hline \multicolumn{5}{|l|}{ SGPT(IU/L) } \\
\hline - Before treatment & $22.62 \pm 15.20$ & $21.90 \pm 10.34$ & $22.26 \pm 12.89$ & 0.830 \\
\hline - After treatment & $19.33 \pm 6.73$ & $19.50 \pm 6.32$ & $19.42 \pm 6.47$ & 0.922 \\
\hline \multicolumn{5}{|l|}{ Alkaline phosphate (IU/L) } \\
\hline - Before treatment & $201.03 \pm 49.83$ & $205.40 \pm 51.1$ & $203.22 \pm 50.09$ & 0.739 \\
\hline - After treatment & $197.18 \pm 40.4$ & $191.07 \pm 42.41$ & $194.13 \pm 41.18$ & 0.570 \\
\hline \multicolumn{5}{|l|}{ Blood urea (mg/dl) } \\
\hline - Before treatment & $21.67 \pm 5.01$ & $24.10 \pm 7.16$ & $22.88 \pm 6.25$ & 0.133 \\
\hline - After treatment & $28.72 \pm 5.54$ & $28.47 \pm 7.47$ & $28.6 \pm 6.52$ & 0.880 \\
\hline \multicolumn{5}{|l|}{ Serum creatinine (mg/dl) } \\
\hline - Before treatment & $0.70 \pm 0.12$ & $0.70 \pm 0.12$ & $0.70 \pm 0.11$ & 1.000 \\
\hline
\end{tabular}




\begin{tabular}{|l|l|l|l|l|}
\hline$\bullet \quad$ After treatment & $0.79 \pm 0.11$ & $0.77 \pm 0.12$ & $0.78 \pm 0.12$ & 0.579 \\
\hline
\end{tabular}

\begin{tabular}{|c|c|c|c|c|}
\hline \multicolumn{5}{|c|}{ Outcome measures assessed in Dysmenorrhea patients. } \\
\hline Outcome measure & $\begin{array}{c}\text { Test group } \\
n=30\end{array}$ & $\begin{array}{c}\begin{array}{c}\text { Control group } \\
\mathbf{n}=\mathbf{3 0}\end{array} \\
\end{array}$ & Total & $P$ value \\
\hline \multicolumn{5}{|l|}{ Primary outcome } \\
\hline Change absent & $12(40 \%)$ & $18(60 \%)$ & $30(50 \%)$ & \multirow{3}{*}{$\begin{array}{c}\mathrm{P}=0.121 \\
\text { Chi-Square } \\
\text { Test }\end{array}$} \\
\hline Change present & $18(60 \%)$ & $12(40 \%)$ & $30(50 \%)$ & \\
\hline Total & $30(100 \%)$ & $30(100 \%)$ & $60(100 \%)$ & \\
\hline \multicolumn{5}{|l|}{ Secondary outcome } \\
\hline Change absent & $0(0 \%)$ & $2(6.7 \%)$ & $2(3.3 \%)$ & \multirow{3}{*}{$\begin{array}{c}\mathrm{P}=0.492 \\
\text { Fisher } \\
\text { Exact Test }\end{array}$} \\
\hline Change present & $30(100 \%)$ & $28(93.3 \%)$ & $58(96.7 \%)$ & \\
\hline Total & $30(100 \%)$ & $30(100 \%)$ & $60(100 \%)$ & \\
\hline
\end{tabular}

Table 16: Therapeutic outcome of Dysmenorrhea patients studied.

\begin{tabular}{|l|l|c|c|c|}
\hline \multirow{2}{*}{$\begin{array}{l}\text { Therapeutic } \\
\text { outcome }\end{array}$} & \multicolumn{2}{|c|}{ Test group } & \multicolumn{2}{c|}{ Control group } \\
\cline { 2 - 5 } & \multicolumn{1}{|c|}{ BT } & AT & BT & AT \\
\hline VAS & $7.67 \pm 1.4$ & $5.70 \pm 1.26$ & $7.43 \pm 1.28$ & $5.97 \pm 1.16$ \\
\hline VMSS & $2.47 \pm 0.68$ & $1.73 \pm 0.45$ & $2.40 \pm 0.50$ & $2.00 \pm 0.26$ \\
\hline
\end{tabular}

Discussion: The study entitled "Effect of Habbul Ghar and Maul Asal in Primary Dysmenorrhea- A Randomized standard controlled clinical study" was conducted in the Dept. of Ilmul Qabalat wa Amraze Niswan, National Institute of Unani Medicine Hospital Bengaluru during 2016-2017. Patients $(n=100)$ of dysmenorrhea were assessed for eligibility, among which 10 patients denied to participate in study, 100

\section{Age:}

Dysmenorrhea is the most common disorder in women of reproductive age. ${ }^{10}$ The Mean $\pm \mathrm{SD}$ of age of the participants included in the present study were $24.33 \pm 6.61$ and $26.13 \pm 6.56$. maximum number of patients belongs to age group 20-30 years i.e. $25(41.7 \%)$. Followed by $31-40$ years i.e. $18(30 \%)$, <20 years i.e. $17(28.3 \%)$ with a $\mathrm{p}$ value $\mathrm{P}=0.294$, which is not significant in the test and control group respectively (table 2). This study results are consistent to studies conducted by kural MR et al, ${ }^{11}$ the average age of the participants was $20.4 \pm 1.8$ years, ranging from 17-25 years. our result similar to the results of Habibi $\mathrm{N}$ et al, ${ }^{12}$ who reported mean age of the participants was ranged from $18-27$ years mean $(20.69 \pm 1.59)$. our result similar to the study result of Najifi et al, ${ }^{13}$ who reported mean age of the participant in the study was $22.2 \pm 2.18$ years patients were accepted for enrollment. Out of 100, 30 patients were excluded, 60 patients who fulfilled the inclusion criteria were randomly allocated in two groups; 30 in test and 30 in control and assessed for subjective and objective parameters of dysmenorrhea. The study design was single blind, randomized controlled study. Efficacy assessment was based on VAS and VMSS.

(range 19-30 years). Primary dysmenorrhea is defined as menstrual pain in the absence of any organic pathology, ${ }^{3}$ and is most common in women under the age of $25 .{ }^{6}$

\section{Socioeconomic status:}

In present study $18(30 \%)$ patients belong to Lower Middle class, $18(30 \%)$ patients belong to upper lower class, $17(28.3 \%)$ patients belong to upper middle and $7(11.7 \%)$ patients belong to upper class with a $p$ value of 0.046*, Which is significant among test group and control group respectively (table 2 ). This study results consistent with Omidvar $\mathrm{S}$ et $a l,{ }^{14}$ who reported dysmenorrhea present in $27.3 \%$ lower socioeconomic status, $60.9 \%$ in middle class patients and $11.8 \%$ in higher socioeconomic status patients. This study shows that it was common in patients with upper middle and lower middle socio economic status and it is a fact that 
ISSN 2250-3153

patients attending the NIUM OPD are from upper middle income group.

\section{Education:}

In our study 4(6.7\%) patients were illiterate, 4(6.7\%) patients studied up to primary education, $6(10 \%)$ patients had post-graduation degree, $13(21.7 \%)$ had high school education, 16(26.7\%) patients had graduation degree, and maximum number of patients belongs to secondary education i.e. 19(31.7\%) with a p value 0.271 which is not significant in test and control group (table 2). According to Khodakarami $\mathrm{B}$ et al, ${ }^{15}$ dysmenorrhea in high school grade students $130(81.19 \%)$, grade one students $130(92.41 \%)$, grade two students $157(86.69 \%)$, grade three students $77(78.71 \%)$ and pre university level $494(85.32 \%)$. This results contrary to the present study results because of different setting.

\section{Habitat:}

In the present study 58(96.7\%) patients were from urban area and $2(3.3 \%)$ patients were from rural area with a $p$ value of 1.000 , which is not significant in the test and control group respectively (table 2). This study results consistent to study conducted by Avasrala KA et al, ${ }^{16}$ who reported dysmenorrhea present in 53\% urban population and $44 \%$ rural population. Present study results consistent to study conducted by Sinha et al., who reported girls with dysmenorrhea $74.4 \%$ in urban schools and $72.7 \%$ in rural school. Study conducted by Madhubala C et $a l^{17}$ who reported prevalence of dysmenorrhea was $81.5 \%$ in rural area, and $76 \%$ in urban girls, it was contradictory to the present study, may be due to NIUM hospital is situated in metropolitan city, Bengaluru, that might be the reason behind maximum no. of patients in this study being from urban area.

\section{Diet:}

In this study $38(63.3 \%)$ patients had mixed dietary habit and $22(36.7 \%)$ patients were purely vegetarians with a $\mathrm{p}$ value of 0.284 , not significant in the test and control group respectively (table 2). High consumption of sugars, salty snacks, sweets and desserts, tea and coffee, is associated with increased risk of dysmenorrhea, study conducted by Barnard et $a l^{18}$ who reported that intervention by a low fat vegetarian diet reduces the intensity of dysmenorrhea. ${ }^{16}$ As per unani text consumption of ghaleez aghdhyia (heavy diet), increases the viscosity of blood and lead to the formation of sudda, hence blood cannot flow easily through minute blood vessels. ${ }^{19}$ So that uterus undergoes forceful contraction with spas nmm during menses to expelled out the morbid viscous matter which result in pain. ${ }^{20,21}$

\section{Religion:}

In the present study maximum number of patients $36(60 \%)$ were belong to Muslim religion and $24(40 \%)$ were Hindu religion with a p-value of 0.598 not significant in the test and control group respectively (table 2). Study conducted by Omidvar S et al, ${ }^{117}$ who reported majority of patients belonged to Hindu families i.e. $84 \%$ while those from Islam, Christianity and other religions varied from $1.3-12.3 \%$. It was contradictory to the present study, this difference may be due to different settings and in NIUM hospital mostly patients come from Muslim community that might be the reason behind maximum no. of patients in this study being Muslims.

\section{Age at menarche (years):}

In the present study the mean age of menarche was $12.30 \pm 0.95$ and $12.40 \pm 0.81$, maximum no. of patients belongs to age group 12 years i.e. $26(43.3 \%)$ followed by 13 years i.e. $22(36.7 \%)$, 11 years i.e. $9(15 \%), 15$ years i.e. $2(3.3 \%)$ and 14 years i.e. $1(1.7 \%)$ with a p- value 0.664 , not significant in test and control group respectively (table 3). Present results are consistent with Sinha S et $a l,{ }^{22}$ and Armour M et $a l,{ }^{5}$ who have reported in their study the mean age at menarche was 12.87 years $(\mathrm{SD} \pm 1.45)$ and 12.7 (1.5) respectively and found no significant relationship between age of menarche and dysmenorrhea. This study results consistent to the study results conducted by Khodakarami B et al, ${ }^{14}$ the age at menarche was found to be $12.92 \pm 1.05$ years. According to unani physicians, menstruation begins in the age of 10 years and the maximum age limit is 14 years. ${ }^{23}$

\section{Mizaj:}

In the present study the highest prevalence of dysmenorrhea was observed in women with damwi mizāj $21(35 \%)$, followed by saudāwi mizāj 17(28.3\%), balghami mizāj $15(25 \%)$ and safrāwi mizāj $7(11.7 \%)$ with a $p$ value of 0.284 which is significant in the test and control group respectively as assessed by temperament scale (table 6). This study results consistent to the study conducted by Zaidi S et al, ${ }^{24} 40.81 \%$ patient were from damwi mizaj, $21.76 \%$ patients were from balghami mizaj and $37.41 \%$ patients were from safrāwi mizaj. There is no direct evidence showing the type of $m i z \bar{a} j$ found in women affected with dysmenorrhea. A similar larger trial purely based on unani parameters should be conducted with the main objective of assessment of mizāj for further establishment of facts.

\section{Subjective parameters:}

In this study nausea present in $20.0 \%$ patients, vomiting in $43.4 \%$, diarrhea $13.3 \%$, giddiness $36.7 \%$ patients and head ache in $53.3 \%$ patients. According to the study conducted by Heba A et al, ${ }^{25}$ Nausea present in $11.3 \%$ patients, vomiting present in $10.9 \%$ patients, diarrhea present in $11.7 \%$ patients dizziness present in $15.5 \%$ patients and head ache present in $18.2 \%$ patients, this study results are contradictory to the present study results, which may be due to different settings

\section{Objective parameters}

\section{Visual analogue scale:}

In the test group mean score of VAS was $7.67 \pm 1.4$ before treatment and after treatment it was $5.70 \pm 1.26$ which was strongly significant $\left(\mathrm{p}<0.001^{* *}\right)$. In control group mean score of VAS before treatment which was $7.43 \pm 1.28$ and after treatment it was $5.97 \pm 1.16$ which was statistically strongly significant with a $\mathrm{p}<0.001^{* *}$ (table 12). In 
intergroup comparison results indicated that Habbulghar was found to be more effective than mefenamic acid.

\section{Verbal multidimensional scoring system:}

In the test group mean score of VMSS was $2.47 \pm 0.68$ before treatment and after treatment it was $1.73 \pm 0.45$ which was strongly significant $(<0.001 * *)$. In control group mean score of VMSS before treatment which was $2.40 \pm 0.50$ and after treatment it was $2.00 \pm 0.26$ which was statistically strongly significant with a $\mathrm{p}$ value of $<0.001 * *$ (table 13). In intergroup comparison results indicated that Habbul-ghar was found to be more effective than mefenamic acid.

\section{Safety profile}

In this study no adverse effects were observed as safety parameters blood urea, serum creatinine, SGOT, SGPT, serum alkaline phosphatase was found to be in the normal range and showed no statistical significance on pre and post-test comparison were within normal limits before and after the study (table 14).

\section{Adverse effects}

No adverse effects were reported with regard to test and control during consumption; hence in the present study both drugs were safe clinically.

\section{Outcome measures: (table 15)}

\section{Primary outcome}

Based on primary outcome out of 60 patients changed found in all 30 patients (18 in test group and 12 in control group) and patients were categorized into complete relief, partial relief and no relief in subjective parameters before and after treatment as follows:

\section{Nausea:}

In this study, in the control group out of 30 patients, 6 were having nausea, while there were no patients in the test group. In the control group out of 6 patients, 2 patients had complete relief and 4 patients were having mild nausea means that 5 patients were partially relieved from nausea. There were no patients in the test group having nausea.

\section{Vomiting:}

In this study 6 patients in the control group and 7 patients in test group were having vomiting. Out of 6 patients, 3 patients having mild and 3 patients were having moderate vomiting. In test group out of 7 patients out of which 2 were having mild and 5 were having moderate vomiting, 2 patients had complete relieved in control group while all over 11 patients were partially relieved.

\section{Giddiness:}

Out of 30 patients in the test group 10 patients were having giddiness in the test group and 2 patients were having giddiness in the control group.1 patient got complete cure in test group while 9 patients were partially relieved but in control group 2 patients were partially relieved, no one got complete cure.

\section{Diarrhoea:}

In the present study in test group 1 patient was having diarrhea in the test group while in control group 3 patients were having diarrhea. Both in test group and control group patients were partially got relived from diarrhea there was no complete cure in both the groups.

\section{Head ache:}

In the present study in test group out of 30 patients, 11 patients were having head ache where as in the control group 5 patients were having head ache. No patient had complete relieved in both the test and control group, all over patients were partially relieved.

\section{Secondary outcome.}

Based on secondary outcome out of 60 patients changed was found in 30 patients (18 in the test group and 12 in control group) after treatment in objective parameters i.e. VAS and VMSS in test and control group respectively. VAS in test group mean score was $7.67 \pm 1.4$ before treatment and after treatment $5.70 \pm 1.26$ where as in control group mean score before treatment it was $7.43 \pm 1.28$ and after treatment it was $5.97 \pm 1.16$ which was statistically strongly significant $(\mathrm{p}<0.001)$ in both the groups. In test group mean score of VMSS before treatment was $2.47 \pm 0.68$ and after treatment it was $1.73 \pm 0.45$ where as in the control group mean score of VMSS before treatment it was $2.40 \pm 0.50$ and after treatment it was $2.00 \pm 0.26$ which was statistically strongly significant $(\mathrm{p}<0.001)$ in both groups.

\section{Therapeutic outcome}

In present study results were analyzed on the basis of VAS and VMSS scoring which was strongly significant $(\mathrm{p}<0.001)$ in both the groups (table 16).

\section{Conclusion:}

In conclusion result of this study validates the claims of unani scholars and it is specific for the treatment of dardi- rahim, Habbul-ghar and Maul Asal has a noticeable efficacy and safety in dysmenorrhea. The data suggest that test drug was equally effective as control drug, as it possesses musakkin-i-auja'a, muhallil-i-waram, mudirr$i$-hayd properties. It helps in easy flow of menstruation and relieve the pain.

Recommendation: As dysmenorrhea is widely prevalent and common complaint with adverse impact on quality of life which sometimes results in activity restriction. Therefore, this complaint should be taken into proper consideration to improve the quality of reproductive health. Moreover, there has been increasing interest of alternative treatment now. Women can use herbal remedies more comfortable in dysmenorrhea. Further, double- blind, randomized controlled trials on larger sample size for longer duration are recommended.

\section{References:}

1. Kumaram AS. Essentials of Gynaecology. New Delhi: Jaypee Brothers medical publishers $(\mathrm{P})$ Limited; 2005:55-62. 
2. Zaidi SMA, Khatoon K, Aslam KM. Role of herbal medicines in Usr-e-tams (dysmenorrhoea). J. Acad. Indus. Res 2012 Aug;1(3):113-17.

3. Konar H. D.C. Datta's textbook of gynaecology $6^{\text {th }}$ ed. Calcutta: New central book agency private limited; 2013:171-74.

4. Monga A. Gynaecology by Ten Teachers $18^{\text {th }}$ ed. Chennai: Book power ELST ;2006: 49-50.

5. Armour M, Dahlen HG, Zhu X, Farquhar C, Smith CA. The role of treatment timing and mode of stimulation in the treatment of primary dysmenorrhea with acupuncture: An exploratory randomized controlled trial. PIOS one $2017 \mathrm{Jul}$ 12;12(7):1-20.

6. Kannan P, Claydon LS. Some physiotherapy treatments may relieve menstrual pain in women with primary dysmenorrhea: a systematic review. Journal of physiotherapy 2014 Mar 1;60(1):1321.

7. Gebeyehu MB, Mekuria AB, Tefera YG, Andarge DA, Debay YB, Bejiga GS, Gebresillassie BM. Prevalence, impact, and management practice of dysmenorrhea among University of Gondar Students, Northwestern Ethiopia: a cross-sectional study. International journal of reproductive medicine 2017;2017.

8. Yang M, Chen X, Bo L. Moxibustion for pain relief in patients with primary dysmenorrhea: Study Protocol for A Randomized controlled trial $2017 \mathrm{Feb} ; 12(2): 1-17$.

9. Khan MA, Kabeeruddin M. Akseer azam (Alakseer). New Delhi: Idarae kitabus shifa; 2011 Jan: 780-99.

10. Patel PA, Karelia BN, Piparva KG. International journal of pharmaceutical science and research Oct 2016;7(11):4556-60.

11. Kural M, Noor NN, Pandit D, Joshi T, Patil A. Menstrual characteristics and prevalence of dysmenorrhea in college going girls. Journal of family medicine and primary care 2015 Jul;4(3):426.

12. Habibi N, Huang MS, Gan WY, Zulida R, Safavi SM. Prevalence of primary dysmenorrhea and factors associated with its intensity among undergraduate students: a cross-sectional study. Pain Management Nursing 2015 Dec $1^{\text {st }}$ ;16(6):855-61.

13. 116. Najafi N, Khalkhali H, Tabrizi FM, Zarrin R. Major dietary patterns in relation to menstrual pain: a nested case control study. BMC women's health 2018 Dec;18(1):69.

14. Omidvar S, Bakouei F, Amiri FN, Begum K. Primary dysmenorrhea and menstrual symptoms in Indian female students: prevalence, impact and management. Global journal of health science 2016 Aug;8(8):135.

15. Khodakarami B, Masoomi SZ, Faradmal J, Nazari M, Saadati M, Sharifi F. The severity of dysmenorrhea and its relationship with body mass index among female adolescents in Hamadan, Iran. Journal of Midwifery and Reproductive Health 2015 Oct 1;3(4):444-50.

16. Avasarala AK, Panchangam S. Dysmenorrhea in different settings: Are the rural and urban adolescent girls perceiving and managing the dysmenorrhea problem differently? Indian journal of community medicine: official publication of Indian Association of Preventive \& Social Medicine 2008 Oct;33(4):246.

17. Madhubala C, Jyoti K. Relationship between dysmenorrhea and body mass index in adolescents with rural versus urban variation. The journal of obstetrics and gynecology of India 2012 Aug;62(4):442445.

18. Khan HA. Haziq. Karachi: Madina publishing company; 1983: 467-71.

19. Sina I. Al Qanoon Fit Tib (Urdu translation: Kantoori G H) Vol II. New Delhi: Idarae kitabus shifa; 2003: 1094-95, 1096- 1118.

20. Sultana A, Khan A, Nawaz QQ and Syed L. Atiopathogenesis and clinical features of dysmenorrhea (Usre-i-tams) in traditional unani medicine and contemporary era: A literary research. TANG (Humanitas medicine) 2016 Feb;1(6):1-7.

21. Sinha S, Srivastava JP, Sachan B, Singh RB. A study of menstrual pattern and prevalence of dysmenorrhea during menstruation among school going adolescent girls in Lucknow district, Uttar Pradesh, India. International Journal of Community Medicine and Public Health 2017 Feb 3;3(5):1200-3.

22. Ali HAS. Zakhira Sabit bin Qarat. AMU; 1987 :301.

23. Zaidi S. Study of spasmodic dysmenorrhea in reference to treatment (mizaj) in adolescent girls. J bio. chem. Research 2016; 33 (1):154-164.

24. 127. Helwa HA, Mitaeb AA, Al-Hamshri S, Sweileh WM. Prevalence of dysmenorrhea and predictors of its pain intensity among Palestinian female university students. BMC women's health 2018 Dec;18(1):18. 